\title{
The Corrosion of Selected Alloys in Eutectic Lithium-Sodium-Potassium Carbonate at $900^{\circ} \mathrm{C}$
}

R. T. Coyle

T. M. Thomas

Paul Schissel

January 1986

Prepared under Task No. $\mathbf{5 1 0 1 . 5 1}$

FTP No. 463

Solar Energy Research Institute

A Division of Midwest Research Institute

1617 Cole Boulevard

Golden, Colorado 80401

Prepared for the

U.S. Department of Energy

Contract No. DE-AC02-83CH10093 


\section{DISCLAIMER}

This report was prepared as an account of work sponsored by an agency of the United States Government. Neither the United States Government nor any agency Thereof, nor any of their employees, makes any warranty, express or implied, or assumes any legal liability or responsibility for the accuracy, completeness, or usefulness of any information, apparatus, product, or process disclosed, or represents that its use would not infringe privately owned rights. Reference herein to any specific commercial product, process, or service by trade name, trademark, manufacturer, or otherwise does not necessarily constitute or imply its endorsement, recommendation, or favoring by the United States Government or any agency thereof. The views and opinions of authors expressed herein do not necessarily state or reflect those of the United States Government or any agency thereof. 


\section{DISCLAIMER}

Portions of this document may be illegible in electronic image products. Images are produced from the best available original document. 
$\pi$

$\nabla$

$B$

$\square$

$\square$

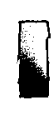

$\nabla$

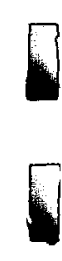

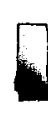

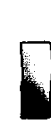

$B$

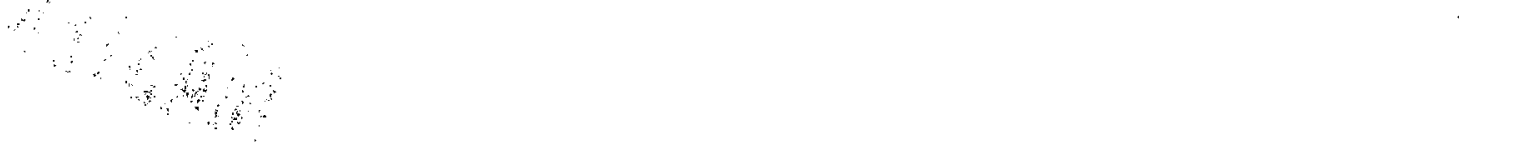

and 
This progress report was prepared for the Energy Storage Program under FY 1984 funding from the Division of Energy Storage Technology of the U.S. Department of Energy. It reports progress on studies of the corrosion of several superalloys in eutectic lithium-sodium-potassium carbonate at $900^{\circ} \mathrm{C}$ obtained during the period October 1984 to April 1985. These alloys are candidates for short-term compatibility (60 days) to contain the carbonate salt for pilot-scale evaluation of advanced solar thermal energy storage systems. Metallographic examination of most of the specimens was funded by the Solar Thermal Technology Program.

We acknowledge the contributions made to this work by Yvonne Shinton and Richard Burrows of the Solar Energy Research Institute and helpful discussions with Bob Bradshaw of Sandia National Laboratories, George Lai of the Cabot Corporation, and Dave Shores of the University of Minnesota.

\section{DISCLAIMER}

This report was prepared as an account of work sponsored by an agency of the United States Government. Neither the United States Government nor any agency thereof, nor any of their employees, makes any warranty, express or implied, or assumes any legal liability or responsibility for the accuracy, completeness, or usefulness of any information, apparatus, product, or process disclosed, or represents that its use would not infringe privately owned rights. Reference herein to any specific commercial product, process, or service by trade name, trademark, manufacturer, or otherwise does not necessarily constitute or imply its endorsement, recommendation, or favoring by the United States Government or any agency thereof. The views and opinions of authors expressed herein do not necessarily state or reflect those of the United States Government or any agency thereof.

Approved for

\section{SOLAR ENERGY RESEARCH INSTITUTE}
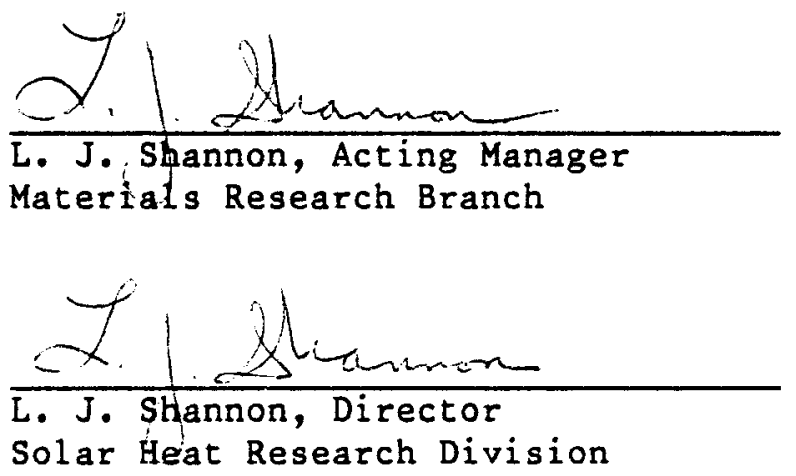
SUMMARY

\section{Objective}

The objective of this work is to identify materials to contain molten eutectic 1 ithium-sodium-potassium carbonate at $900^{\circ} \mathrm{C}$ for use in advanced solar energy storage systems where the molten salt is a sensible heat medium. The nearterm objective of the work was to assess the stability of selected alloys to corrosive attack by the salt at $900^{\circ} \mathrm{C}$ after 60 days of exposure. The purpose was to identify metallic construction materials that could be used in pilotscale studies of about 60 days duration to allow evaluation of heat transfer, fluid flow, and materials compatibility issues in advanced designs.

\section{Discussion}

A number of alloys in exploratory corrosion studies showed promise of sufficient compatibility with molten carbonate salt at $900^{\circ} \mathrm{C}$ to be candidates for use in pilot-scale studies of advanced storage concepts. The alloys that were evaluated in this study were Inconel 600, Hastelloy N, Cabot 201 (nickel), Haynes 556, Cabot 214, and Cabot $800 \mathrm{H}$. These alloys were exposed to $900^{\circ} \mathrm{C}$ eutectic lithium-sodium-potassium carbonate molten salt for times up to 67 days. The weight changes for alloy coupons were monitored for various exposure times in the salt, and the coupons were metallographically examined to determine metal wastage.

It was found that Inconel 600 had metal wastage of $0.17 \mathrm{~mm}$ after 62 days of exposure when the salt was purged with gas containing $22 \%$ oxygen. This alloy under the above purging condition was the most corrosion resistant in these studies and is the best of these candidates for use in pilot-scale studies. In other experiments, where about a tenth of the oxygen concentration was used, the corrosion was much more dramatic $(0.56 \mathrm{~mm}$ after 21 days of exposure). Hastelloy $\mathrm{N}$ also showed less severe corrosion rates with higher oxygen content in the purge gas and nickel showed comparable corrosion behavior with the high oxygen content experiments.

The alloys that were tested only under low oxygen purge conditions, Haynes 556, Cabot $800 \mathrm{H}$, and Cabot 214 showed rapid corrosion. It would be useful to test these under high oxygen conditions. The Cabot 214, an alloy that forms an alumina protective layer, would be especially interesting to test in high oxygen salt since it has been shown that alumina is very corrosion resistant in the molten salt. 


\section{TABLE OF CONTENTS}

Page

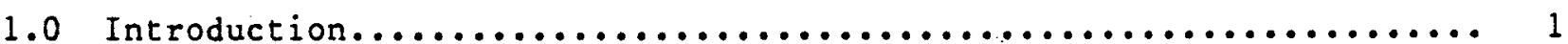

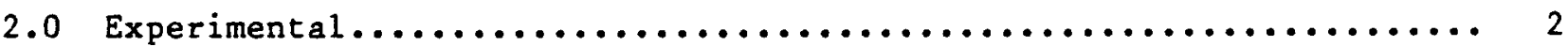

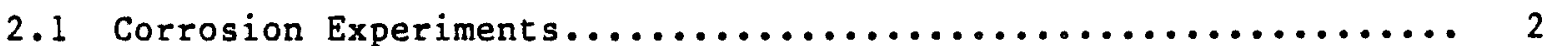

2.2 Weight Change Measurements......................... 2

2.3 Molten-Salt Chemistry............................. 2

2.4 Compositions of the Alloys......................... 4

3.0 Results and Discussion............................. 7

3.1 Corrosion of Inconel $600 \ldots \ldots \ldots \ldots \ldots \ldots \ldots \ldots \ldots \ldots \ldots \ldots \ldots \ldots \ldots$

3.2 Corrosion of Hastelloy N............................. 10

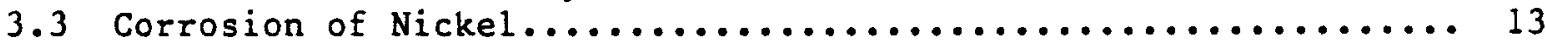

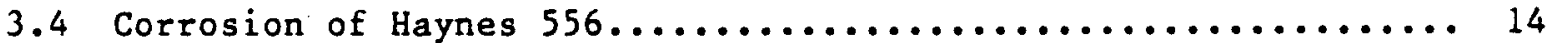

3.5 Corrosion of Cabot 214 and Cabot $800 \mathrm{H} \ldots \ldots \ldots \ldots \ldots \ldots \ldots \ldots \ldots \ldots$

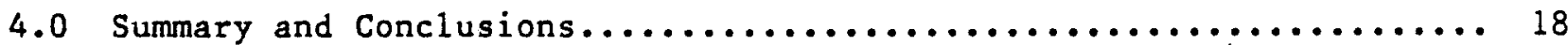

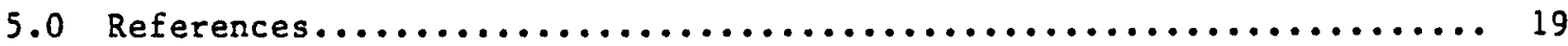




\section{LIST OF FIGURES}

Page

2-1 Illustration of a Crucible for Conducting Molten-Salt Corrosion Experiments...................................... 3

2-2 Schematic of the Quadrupole Mass Spectrometer Gas Analysis System... 5

3-1 Weight Change of Inconel 600 after Exposure to Eutectic LiNaK Salt

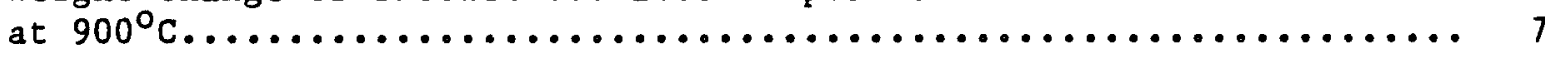

3-2 Metallographic Sections of Inconel 600 Exposed to Eutectic LiNaK

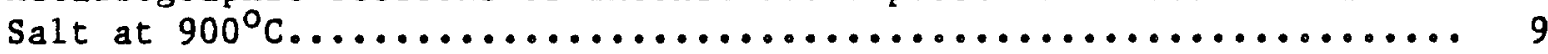

3-3 Weight Change of Hastelloy after Exposure to Eutectic LiNaK Salt

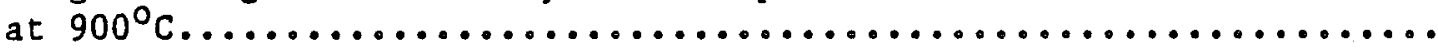

3-4 Metallographic Sections of Hastelloy N Exposed to Eutectic

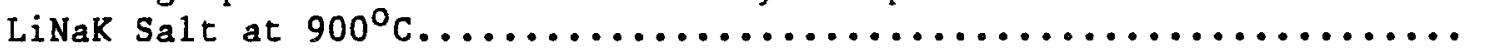

3-5 Weight Change of Nickel after Exposure to Eutectic LiNak Salt at $900^{\circ} \mathrm{C}$.

3-6 Commercial Nickel Alloy, Cabot Alloy 201, after Exposure to Eutectic LiNak Salt at $900^{\circ} \mathrm{C}$ for 60 Days, Bubbled with $71 \%$ Argon-

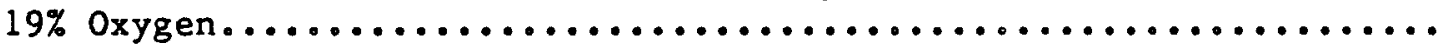

3-7 Weight Change of Haynes 556 ( $\bullet$ Low $\mathrm{O}_{2}$, low $\mathrm{Co}_{2}$ ) and Cabot $800 \mathrm{H}$ ( $\triangle$ low $\mathrm{O}_{2}$, high $\mathrm{CO}_{2}$ ) after Exposure to Eutectic LiNaK Salt

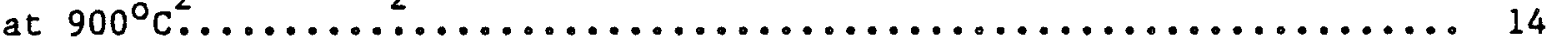

3-8 Metallographic Sections of Haynes 556 after Exposure to Eutectic LiNaK Salt for 3 Days $(A)$ and 6 Days $(B)$ at $900^{\circ} \mathrm{C} \ldots \ldots \ldots \ldots \ldots \ldots$

3-9 SEM and EDS Analysis of Haynes 556 after 6 Days in Eutectic LiNaK

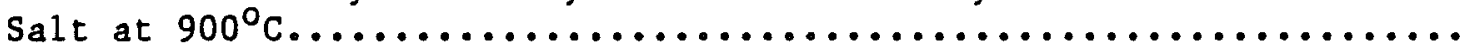




\section{LIST OF TABLES}

Page

2-1 Quadrupole Analysis of the Gasses above the Eutectic LiNaK Salt

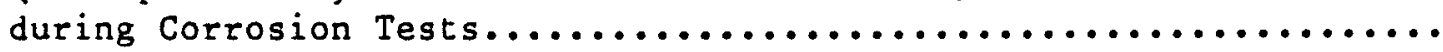

2-2 Nominal Chemical Composition of Alloys under Investigation (wt \%)

3-1 Corrosion Results from Metallography on Inconel 600 Immersed in Eutectic LiNaK Salt at $900^{\circ} \mathrm{C}$ for Two Gas Mixtures Bubbled into

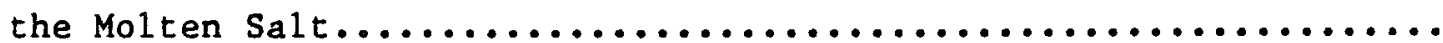

3-2 Corrosion Results from Metallography on Hastelloy $N$ Immersed in Eutectic LiNaK Salt at $900^{\circ} \mathrm{C}$ for Two Gas Mixtures Bubbled into the Molten Salt...................................... 10

3-3 Corrosion Results from Metallography on Cabot 201 Immersed in Eutectic LiNaK Salt at $900^{\circ} \mathrm{C}$ with the Gas Mixture Bubbled

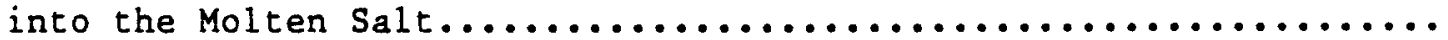


SECTION 1.0

\section{INTRODUCTION}

The Division of Energy Storage Technology of the U.S. Department of Energy is interested in the use of molten salts as high temperature, sensible heat storage media in advanced solar energy storage systems. The objective of the first phase of the work at SERI was to design a containment system and to identify materials for an advanced system with an operating temperature of $900^{\circ} \mathrm{C}$. Previous reports (Coyle et al. 1983, 1984) have presented information on an advanced storage concept. The work presented in this report investigates the compatibility of alloys with a ternary eutectic lithium-sodium-potassium carbonate $\left[(\mathrm{Li}, \mathrm{Na}, \mathrm{K})_{2} \mathrm{CO}_{3}\right]$ molten salt (hereafter referred to as eutectic LiNaK salt) at $900^{\circ} \mathrm{C}$ under various combinations of oxygen potential and acid- ity in the molten salt. These alloys are candidates for use in pilot-scale tests of advanced solar thermal energy storage systems; this requires successful corrosion performance for 60 days at $900^{\circ} \mathrm{C}$. The alloys investigated were ones that showed promise of compatibility with molten carbonate salt at $900^{\circ} \mathrm{C}$ in exploratory corrosion tests done by Coyle et al. (1983).

We present the results of weight change measurements on coupons of Inconel 600, Hastelloy N, nickel, Haynes 556, Cabot 214, and Cabot $800 \mathrm{H}$ after they were immersed in eutectic LiNaK for periods of up to 67 days. We also present the results of metallographic examinations of many of the coupons. 


\subsection{EXPERIMENTAL}

\subsection{Corrosion Experiments}

An illustration of a crucible used for exposing coupons of alloys to molten salt is shown in Figure 2-1. The crucible was made of nominally 99.8\% pure aluminum oxide and contained molten salt about $13 \mathrm{~cm}$ deep. We tested coupons in a crucible, one alloy at a time, and immersed all coupons in the molten salt. The molten-salt temperature was maintained at $900^{\circ} \mathrm{C}$, and the temperature gradient from the top to the bottom of the salt was about $4^{\circ} \mathrm{C}$. The top of the crucible was covered with a water-cooled plate, holding a thermocouple and gas purge tube that were suspended in the crucible. Mass flow controllers maintained a constant flow of purge gas to the crucibles.

The coupons shown in Figure 2-1 were $1.3 \times 1.9 \mathrm{~cm}$ and typically about $0.2 \mathrm{~cm}$ thick. Holes of about $0.4-\mathrm{cm}$ diameter were made in the coupons so we could mount them on $99.8 \%$ pure aluminum oxide sample holders using spacers of this ceramic to separate the coupons. The coupons were cleaned, weighed, and measured before testing.

\subsection{Weight Change Measurements}

Usually three coupons were exposed to molten salt for the desired time and then removed for weighing. These coupons were not returned to the salt, and coupons that were to be tested for longer times were not disturbed at shorter sampling times for examination. We weighed the coupon after exposure to salt by first cleaning adherent salt from the coupon with distilled water, rinsing in acetone, and drying in an oven at $100^{\circ} \mathrm{C}$ for one hour. Care was taken not to remove any of the corrosion product from the surface of the coupon. Weight changes were reported as $\mathrm{mg} / \mathrm{cm}^{2}$ of coupon surface area.

\subsection{Molten-Salt Chemistry}

We used a ternary eutectic salt for these experiments $\left(43.5 \mathrm{~mol} \% \mathrm{Li}_{2} \mathrm{CO}_{3}\right.$, $31.5 \mathrm{~mol} \% \mathrm{Na}_{2} \mathrm{CO}_{3}$, and $25 \mathrm{~mol}^{3} \%$ $\left.\mathrm{K}_{2} \mathrm{CO}_{3}\right)$. The salt was prepared using reagent grade chemicals.

The acidity of the salt and its oxygen potential were controlled by the composition of the purge gas. The gases used are given in Table 2-1. In the experiments with $0.4 \%$ carbon dioxide the purge gas was used to blanket the top of the molten salt, and in experiments where the other two purge gases were used the gas was bubbled into the molten salt to achieve better exchange between the gas and the salt. The purge gases were $\mathrm{Ar}$ and $\mathrm{CO}_{2}$, and in some experiments, $\mathrm{O}_{2}$ was also used. The dependence of corrosion on salt acidity and oxygen potential are discussed by Coyle et al. (1984).

A quadrupole mass spectrometer was used to analyze the composition of the gasses in the volume of space above the molten salt. A schematic of the system used to conduct these analyses is shown in Figure 2-2. This system is discussed in detail by Coyle, Thomas, and Schissel (1985). The results of analyses of the gases above the salt for most of the experiments is shown in Table 2-2.

A significant amount of air was present above the salt in some experiments. This is apparent from examining the quadrupole results in Table 2-1 where nitrogen appeared in the spectra when it was not used in the purge gas. It is also seen in the table that oxygen appeared in 


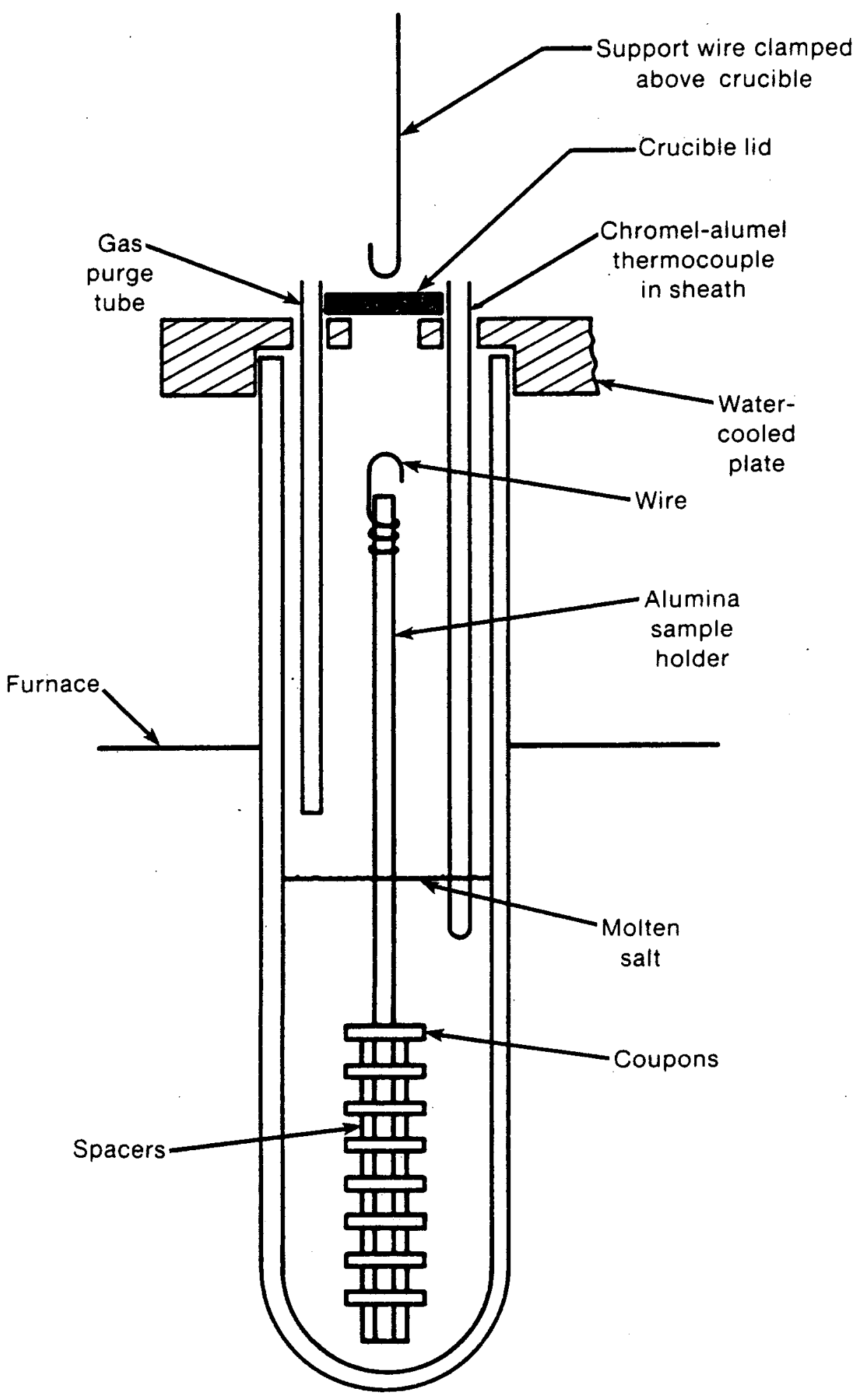

Figure 2-1. Illustration of a Crucible for Conducting Molten Salt Corrosion Experiments 
Table 2-1. Quadrupole Analysis of the Gases above the Eutectic LiNaK Salt during Corrosion Tests

\begin{tabular}{llrrrr}
\hline $\begin{array}{l}\text { Experiment Number } \\
\text { (material tested) }\end{array}$ & $\% \mathrm{Ar}$ & $\% \mathrm{CO}_{2}$ & $\% \mathrm{~N}_{2}$ & $\% \mathrm{O}_{2}$ & $\% \mathrm{Air}$ \\
\hline 1 (Nickel, 99.99\%) & 78 & 22 & $<0.1$ & $<0.1$ & $<0.1$ \\
2 (Inconel 600) & 53.2 & 15.7 & 24.9 & 6.3 & 31 \\
3 (Hastelloy N) & 73.5 & 20.6 & 4.7 & 1.2 & 6 \\
4 (Hastelloy N) & 64.9 & 12.0 & 0.3 & 22.7 & 0.4 \\
5 (Cabot 201) & 55.6 & 9.7 & 13.3 & 21.4 & 16.8 \\
5 (resealed) & 62.5 & 11.3 & 1.3 & 24.9 & 1.6 \\
6 (Inconel 600) & 56.2 & 10.5 & 11.3 & 22.0 & 14.3 \\
\hline
\end{tabular}

${ }^{a}$ Also tested Cabot 201 and Inconel $800 \mathrm{H}$ in this crucible.

experiments 2 and 3 when it was not included in the purge gas. Because oxygen and nitrogen were both entering the crucible an air infiltration was indicated. Resealing of crucible number 5 was attempted after the corrosion experiment; this eliminated most of the air as seen in the table (an improved crucible lid design has further reduced this infiltration for future corrosion experiments).

For the experiments reported in Table 2-1 the purge gas was bubbled into the molten salt during the experiment. Thus, the salt was partially swept free of infiltrated oxygen and nitrogen that had diffused in from the salt-gas interface. In these experiments, 2 and 3 in the table, the oxygen content in the salt is characterized as low (about an order of magnitude lower) compared to experiments 4,5 , and 6 in the table where the oxygen content of the purge gas being bubbled into the salt was about $22 \%$, and is characterized as high.
In earlier experiments, before the quadrupole mass spectrometer was available for analysis, nitrogen gas containing $0.4 \% \mathrm{CO}_{2}$ was used to purge the air space above the molten salt instead of bubbling into the salt as in the later experiments. The acidity of the salt purged with $0.4 \% \mathrm{CO}_{2}$ is characterized as low compared to the $10 \%-20 \% \mathrm{CO}_{2}$ of the later experiments in Table 2-1. An infiltration comparable to that in experiments 2 and 3 of the table most likely occurred in these experiments also, since the same crucible sealing technique was used. Thus, the oxygen potentials in these experiments were probably about the same as in experiments 1,2 , and 3 in the table and are characterized as being low.

\subsection{Compositions of the Alloys}

The compositions of the alloys evaluated for corrosion resistance to eutectic LiNaK are given in Table 2-2. These were taken from vendors' 1 iterature. 


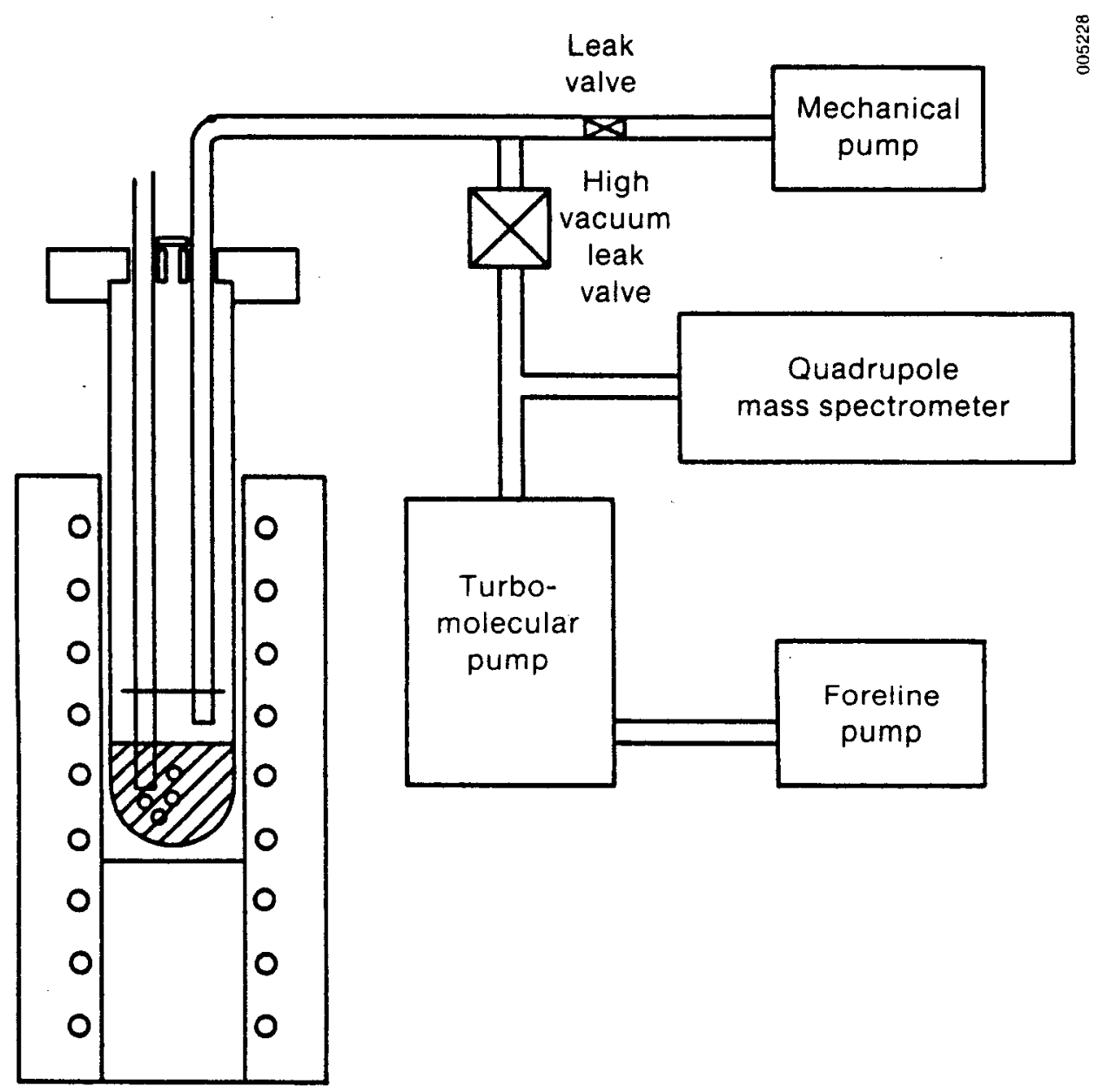

Figure 2-2. Schematic of the Quadrupole Mass Spectrometer Gas Analysis System 
Table 2-2. Nominal Chemical Composition of Alloys under Investigation (wt $z$ ) (The alloys are grouped by type)

\begin{tabular}{|c|c|c|c|c|c|c|c|c|c|c|c|c|}
\hline Alloy & c & $\mathrm{Fe}$ & Ni & Co & Cr & Mo & $w$ & si & $\mathrm{Mn}$ & Al & $\mathbf{T i}$ & Others \\
\hline \multicolumn{13}{|l|}{ Nickel } \\
\hline $\begin{array}{l}\text { pure } \\
\text { Cabot }^{a} 201\end{array}$ & $\overline{0.2+}$ & $\overline{0.4+}$ & $\begin{array}{l}99.99 \\
99.9\end{array}$ & - & - & - & - & $\overline{0.15+}$ & $\overline{0.35+}$ & - & $\overline{0.1+}$ & $\bar{C} u=0.25 t, M g=0.15 t, S=0.005 t$ \\
\hline \multicolumn{13}{|l|}{ Nickel-Chromium } \\
\hline $\begin{array}{l}\text { Cabot alloy } 600 \\
\text { Inconel alloy } 600 \\
\text { Cabot alloy } 214\end{array}$ & $\begin{array}{l}0.08+ \\
0.15 \\
-\end{array}$ & $\begin{array}{l}8 \\
8 \\
2.5\end{array}$ & $\begin{array}{l}74 \\
75 \\
77\end{array}$ & $\ln _{-}^{1+}$ & $\begin{array}{l}15 \\
15 \\
16\end{array}$ & $\overline{-}$ & $\begin{array}{l}- \\
-\end{array}$ & $\begin{array}{l}0.5+ \\
0.5+ \\
-\end{array}$ & $\begin{array}{l}1+ \\
1+ \\
-\end{array}$ & $\begin{array}{l}0.35+ \\
- \\
4.5\end{array}$ & $\begin{array}{c}0.3+ \\
-\end{array}$ & $\begin{array}{l}C u=0.5+, S=0.015+ \\
C u=0.5+, S=0.015+ \\
Y=p r e s e n t\end{array}$ \\
\hline \multicolumn{13}{|l|}{ Iron-Nicke1-Ch romfum } \\
\hline $\begin{array}{l}\text { Cabot alloy } 800 \mathrm{H} \\
\text { Incoloy alloy } 800 \\
\text { Haynes alloy } 556\end{array}$ & $\begin{array}{l}0.08 \\
0.1+ \\
0.1\end{array}$ & $\begin{array}{l}41 \\
43 \\
29\end{array}$ & $\begin{array}{l}32 \\
32 \\
20\end{array}$ & $\frac{2+}{20}$ & $\begin{array}{l}21 \\
21 \\
22\end{array}$ & $\overline{-}$ & $\overline{-}$ & $\begin{array}{l}1+ \\
1+ \\
0.4\end{array}$ & $\begin{array}{l}1.5+ \\
1.5+ \\
1\end{array}$ & $\begin{array}{l}0.4 \\
0.4 \\
0.2\end{array}$ & $\begin{array}{c}0.4 \\
0.4 \\
-\end{array}$ & $\begin{array}{l}\mathrm{Cu}=0.75+, \quad S=0.015+ \\
\mathrm{Cu}=0.75+, \quad S=0.015+ \\
\mathrm{Cb}+\mathrm{Ta}-1, \quad \mathrm{La}=0.2, \quad \mathrm{~N}=0.2, \quad \mathrm{Zr}=0.02\end{array}$ \\
\hline$\frac{\text { H1gh Ref ractory Metals Content }}{\text { Hastelloy }{ }^{\mathrm{a}} \text { alloy N }}$ & 0.06 & $5+$ & 71 & $0.2+$ & 7 & 17 & $0.5+$ & - & - & $0.3+$ & $0.3+$ & $B=0.01+, C u=0.035+$ \\
\hline
\end{tabular}

${ }^{a}$ Cabot, Haynes, and Hastelloy are reglstered trademarks of Cabot Corporation.

b Inconel and Incoloy are registered trademarks of the Inco family of companies.

+Maximum 


\subsection{RESULTS AND DISCUSSION}

The alloys evaluated in these studies were the ones identified by the exploratory corrosion studies of Coyle et al. (1984): Inconel 600, Hastelloy N, nickel, Cabot 214, and Haynes 556. The results are discussed separately for each alloy evaluated.

\subsection{Corrosion of Inconel 600}

The results of weight loss studies on Inconel 600 are presented in Figure 3-1 for three different conditions in the eutectic LiNaK salt. The results are presented as weight change in milligrams per square centimeter for various exposure times in the salt. Each data point in the figure is the average of measurements on three coupons, and the standard deviations are shown by error bars that are one standard deviation on either side of the mean. For points where the standard deviation is small compared with the size of the symbol no error bars are included with the point.

The corrosion experiments were conducted under the three conditions discussed in Section 2.0; these were low oxygen potential and low acidity, low oxygen potential and high acidity, and high oxygen potential and high acidity. Figure $3-1$ shows that for the two series of experiments with low oxygen potential there were weight gains. Weight losses were observed for the series of experiments with high oxygen potential. These weight changes establish that there is an ongoing interaction between the salt and the coupons. However, to determine the amount of metal affected as a result of these changes requires more extensive studies to establish the relationship between weight changes and the accompanying metallographs.

Coyle, Thomas, and Lai (1984) and Bradshaw (1983) have discussed the

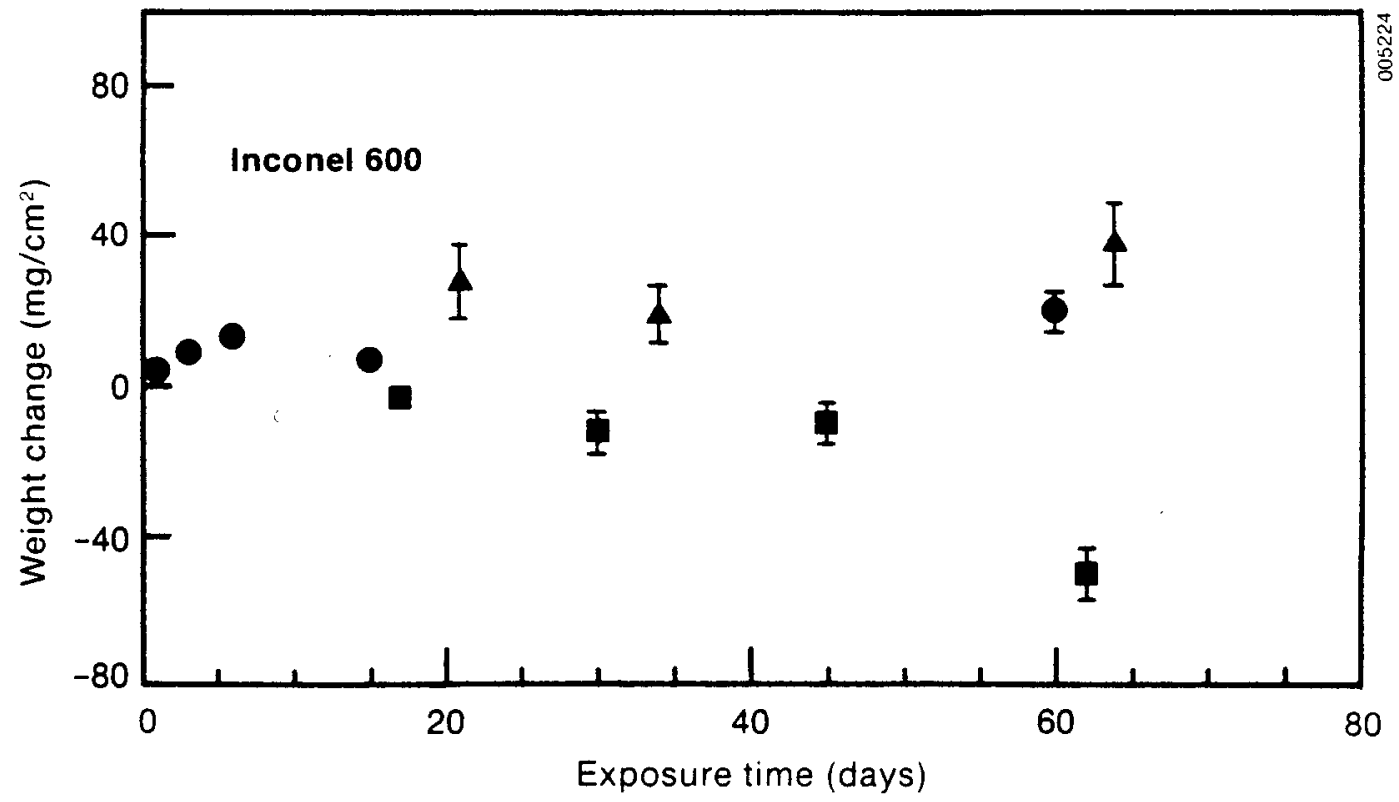

Figure 3-1. Weight Change of Inconel 600 after Exposure to Eutectic LiNaR Salt at $900^{\circ} \mathrm{C}$. Salt conditions: - Low $\mathrm{O}_{2}$, Low $\mathrm{CO}_{2} ; \Delta$ Low $\mathrm{O}_{2}$, $\mathrm{High} \mathrm{CO}_{2} ; \mathrm{High} \mathrm{O}_{2}$, $\mathrm{High} \mathrm{O}_{2}$. 
causes for weight changes for coupons exposed to molten carbonates and molten nitrates, respectively. They reported that the weight changes observed were weight gains caused by the oxidation of metal or weight losses caused by spalling of the corrosion product or the dissolution of alloy components by the molten salt. Weight gains could also result from salt being trapped in a porous scale.

In the experiments on Inconel 600 and on the other alloys discussed later in this section all of the above weight change mechanisms may contribute to the overall weight change of the alloy as discussed by Coyle, Thomas, and Lai (1984) for very similar experiments. Since several weight loss mechanisms were operative in these experiments, the metal loss from the coupon could not be determined from the weight change measurements. Metallographic sections were prepared to evaluate the amount of metal loss from a number of coupons.

The results of metallographic examination of the Inconel 600 are shown in Table 3-1, and some of the micro- graphs from the metallographic sections are shown in Eigure 3-2. Table 3-1 gives the immersion times for the coupons; the metal loss is given in millimeters per side. We determined the metal loss by measuring the thickness of metal remaining after corrosion; an optical micrograph was used. The light areas in the figure show the remaining metal.

The depth of intergranular oxidation (an example of this is the dark line extending into the metal as shown in Figure 3-2c) in the metal is counted as part of the corrosion product.

Although it is speculative, we can estimate the corrosion rates from the data in Tables $3-1,3-2$, and $3-3$ by making assumptions about the progression of metal loss with time. If we assume that the metal loss at about 60 days represents a point along a linear metal loss curve, the corrosion rates would be $1 \mathrm{~mm} / \mathrm{yr}$ per side for the Inconel 600 in the high oxygen potential molten salt. However, to the extent that the corrosion products are protective--and the data in Tables $3-1,3-2$, and $3-3$

Table 3-1. Corrosion Results from Metallography on Inconel 600 Immersed in Eutectic LiNaK Salt at $900^{\circ} \mathrm{C}$ for Two Gas Mixtures Bubbled into the Molten Salt

\begin{tabular}{ccc}
$\begin{array}{c}\text { Oxygen Potential } \\
\text { (Quadrupole Analysis) }\end{array}$ & $\begin{array}{c}\text { Immersion } \\
\text { Time (days) }\end{array}$ & $\begin{array}{c}\text { Metal } \\
\text { Loss (mm/side) }\end{array}$ \\
\hline Low & 21 & 0.56 \\
$\left(16 \% \mathrm{CO}_{2}, 6 \% \mathrm{O}_{2}\right)$ & 64 & $>0.59$ \\
\hline & 17 & 0.12 \\
$\mathrm{High}$ & 30 & 0.08 \\
\hline $\left.\mathrm{CO}_{2}, 22 \% \mathrm{O}_{2}\right)$ & 62 & 0.17 \\
\hline
\end{tabular}



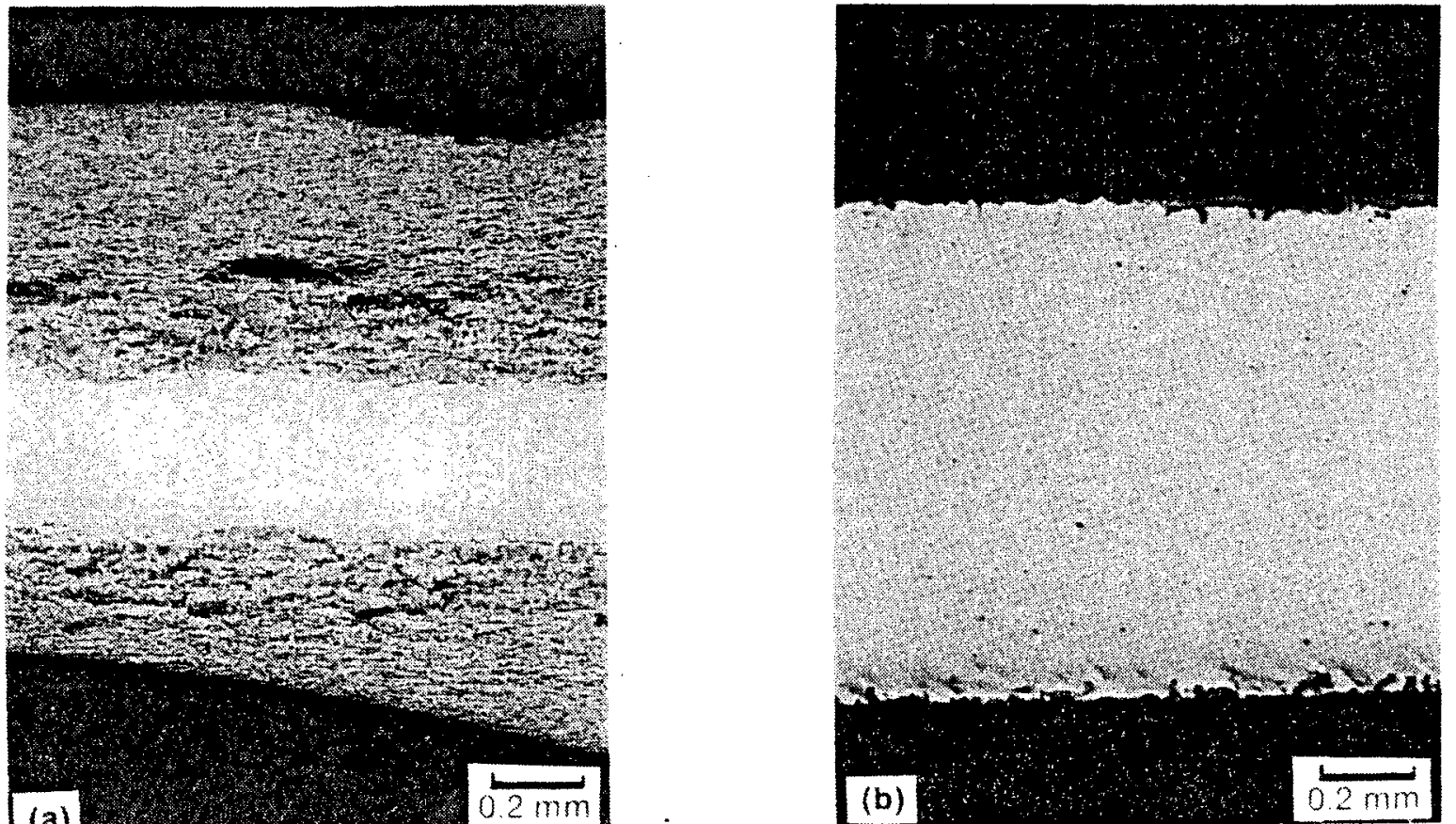

(a)
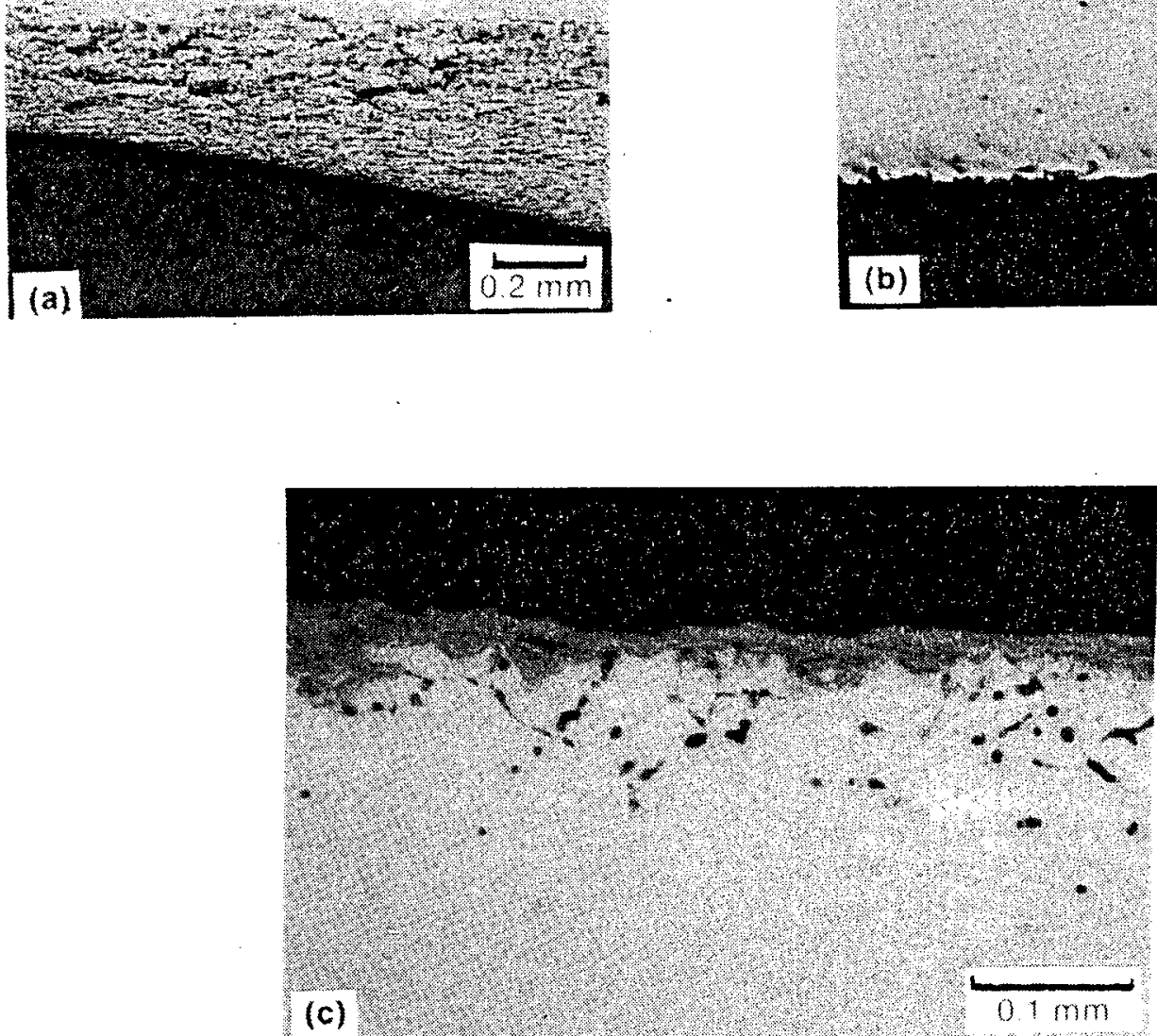

Figure 3-2. Metallographic Sections of Inconel 600 Exposed to Eutectic LiNaR Salt at $900^{\circ} \mathrm{C}$ 
Table 3-2. Corrosion Results from Metallography on Hastelloy $N$ Immersed in Eutectic LiNaR Salt at $900^{\circ} \mathrm{C}$ for Two Gas Mixtures Bubbled into the Molten Salt

\begin{tabular}{ccc}
\hline $\begin{array}{c}\text { Oxygen Potential } \\
\text { (Quadrupole Analysis) }\end{array}$ & $\begin{array}{c}\text { Immersion } \\
\text { Time (days) }\end{array}$ & $\begin{array}{c}\text { Metal Loss } \\
\text { (mm/side) }\end{array}$ \\
\hline $\begin{array}{c}\text { Low } \\
\left(21 \% \mathrm{CO}_{2}, 1 \% \mathrm{O}_{2}\right)\end{array}$ & 21 & 0.31 \\
& 67 & $>0.62$ \\
\hline$\left(12 \% \mathrm{CO}_{2}, 23 \% \mathrm{O}_{2}\right)$ & 17 & 0.12 \\
& 30 & 0.22 \\
\end{tabular}

Table 3-3. Corrosion Results from Metallography on Cabot 201 Immersed in Eutectic LiNaR Salt at $900^{\circ} \mathrm{C}$ with the Gas Mixture Bubbled into the Molten Salt

\begin{tabular}{|c|c|c|}
\hline $\begin{array}{c}\text { Oxygen Potential } \\
\text { (Quadrupole Analysis) }\end{array}$ & $\begin{array}{l}\text { Immersion } \\
\text { Time (days) }\end{array}$ & $\begin{array}{l}\text { Metal Loss } \\
(\mathrm{mm} / \mathrm{side})\end{array}$ \\
\hline \multirow{3}{*}{$\underset{\left(10 \% \mathrm{CO}_{2} ; 21 \% \mathrm{O}_{2}\right)}{\mathrm{High}}$} & 17 & $0.5^{a}$ \\
\hline & 30 & $0.36^{b}$ \\
\hline & 60 & $0.5^{a}$ \\
\hline
\end{tabular}

antergranular oxidation.

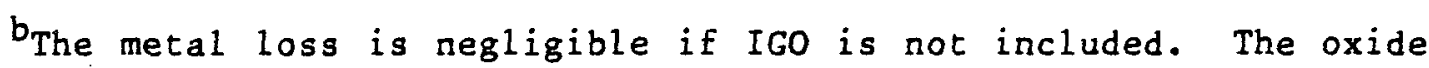
scale for the 17,30 , and 60 day tests were $0.01 \mathrm{~mm}, 0.03 \mathrm{~mm}$, and $0.03 \mathrm{~mm}$, respectively.

indicate that the metal loss is not increasing linearly with time, which may indicate the formation of a protective corrosion product--the corrosion rates could be substantially below this. The estimated corrosion rate from the low oxygen potential experiment appears to be a factor of four higher upon comparison of the data found in Table 3-1. This difference in the extent of corrosion for the two conditions is borne out by comparing the micrographs in Figure 3-2a,b.

\subsection{Corrosion of Hastelloy $\mathrm{N}$}

The results of weight loss studies on Hastelloy $N$ are presented in Figure 3-3 or the same oxygen potential and acidity conditions used for the Inconel 600 studies discussed in Section 3.1. The experiments were done in eutectic LiNaK salt at $900^{\circ} \mathrm{C}$. Figure $3-3$ shows that all of the coupons of Hastelloy $N$ experienced weight loss under the conditions imposed. Similar weight change curves were observed for the 


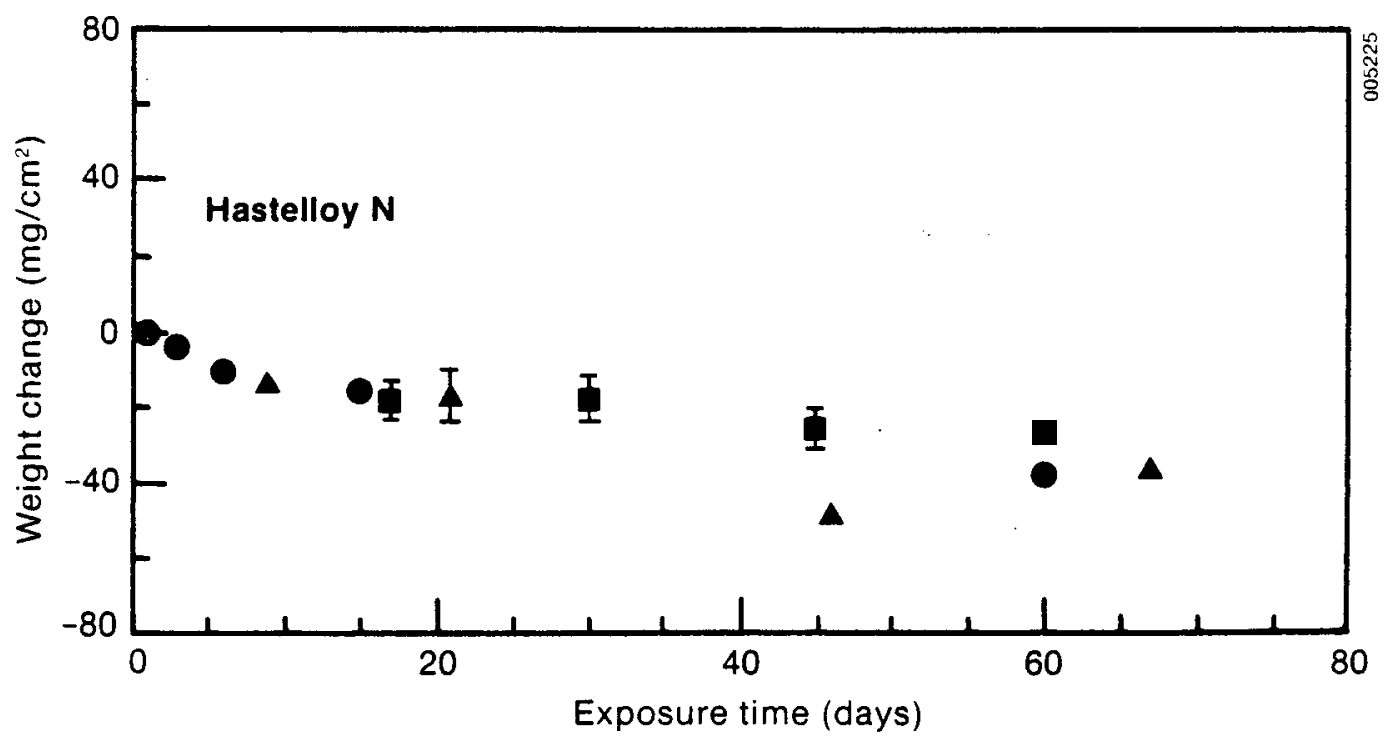

Figure 3-3. Weight Change of Hastelloy after Exposure to Eutectic LiNaK Salt at $900^{\circ} \mathrm{C}$. Salt conditions: - low $\mathrm{O}_{2}$, low $\mathrm{CO}_{2} ; \wedge$ low $\mathrm{O}_{2}$, high $\mathrm{CO}_{2} ;$ high $\mathrm{O}_{2}$, high $\mathrm{CO}_{2}$.

three conditions. Metallographic examination was done to determine the metal loss for the coupons.

The results of metallographic examinations of coupons from the two high acidity experiments are presented in Table 3-2. Some of the micrographs from the metallographic sections are shown in Figure 3-4. The results in Table 3-2 show that, as with the Inconel 600 , substantially less metal loss occurred for the coupons rested in the high oxygen potential. This was unexpected in view of the similar weight loss curves seen for the two conditions in Figure 3-3.

The micrographs in Eigure $3-4$ show that the corrosion product on the coupons tested in a high oxygen potential consists of two distinct layers with the outer layer developing between 30 and 60 days and the inner layer remaining constant in thickness over this period. The inner layer has an appearance similar to the corrosion product in Figure 3-4, where the coupon was tested under low oxygen potential.
We can speculate that the reduced metal loss for the high oxygen potential is related to the presence of the outer part of the scale, which limits access to the metal by the molten salt.

A comparison of the results for Hastelloy $N$ with those for Inconel 600 shows that the Hastelloy $N$ has less intergranular oxidation. However, if the metal loss rate for the Hastelloy $\mathbf{N}$ is calculated assuming a linear loss rate, as was done for the Inconel 600 , then the corrosion rate would be $1.5 \mathrm{~mm} / \mathrm{yr}$ per side compared with $1 \mathrm{~mm} / \mathrm{yr}$ per side for the Inconel 600. However, to the extent that the corrosion products are protective, which is suggested by comparing the $30-$ and 60-day data in Table 3-2 where little additional metal loss is seen, the corrosion rate could be substantially below this for materials corroded in a high oxygen potential environment over longer periods. Further corrosion experiments and metallographic analyses would be required to verify this conclusion, which now should be 

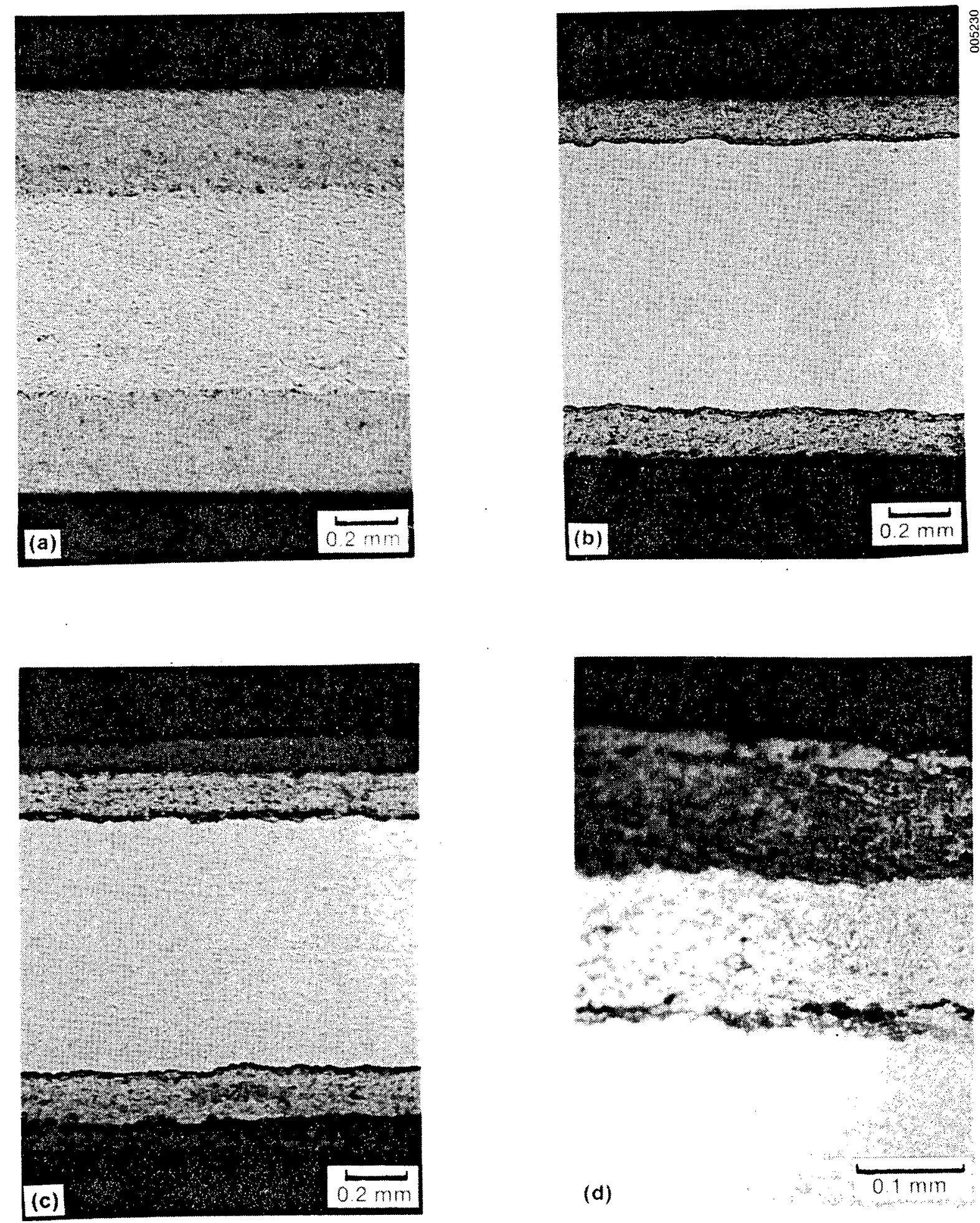

Figure 3-4. Metallographic Sections of Hastelloy $N$ Exposed to Eutectic LiNaR Salt at $900^{\circ} \mathrm{C}$ 


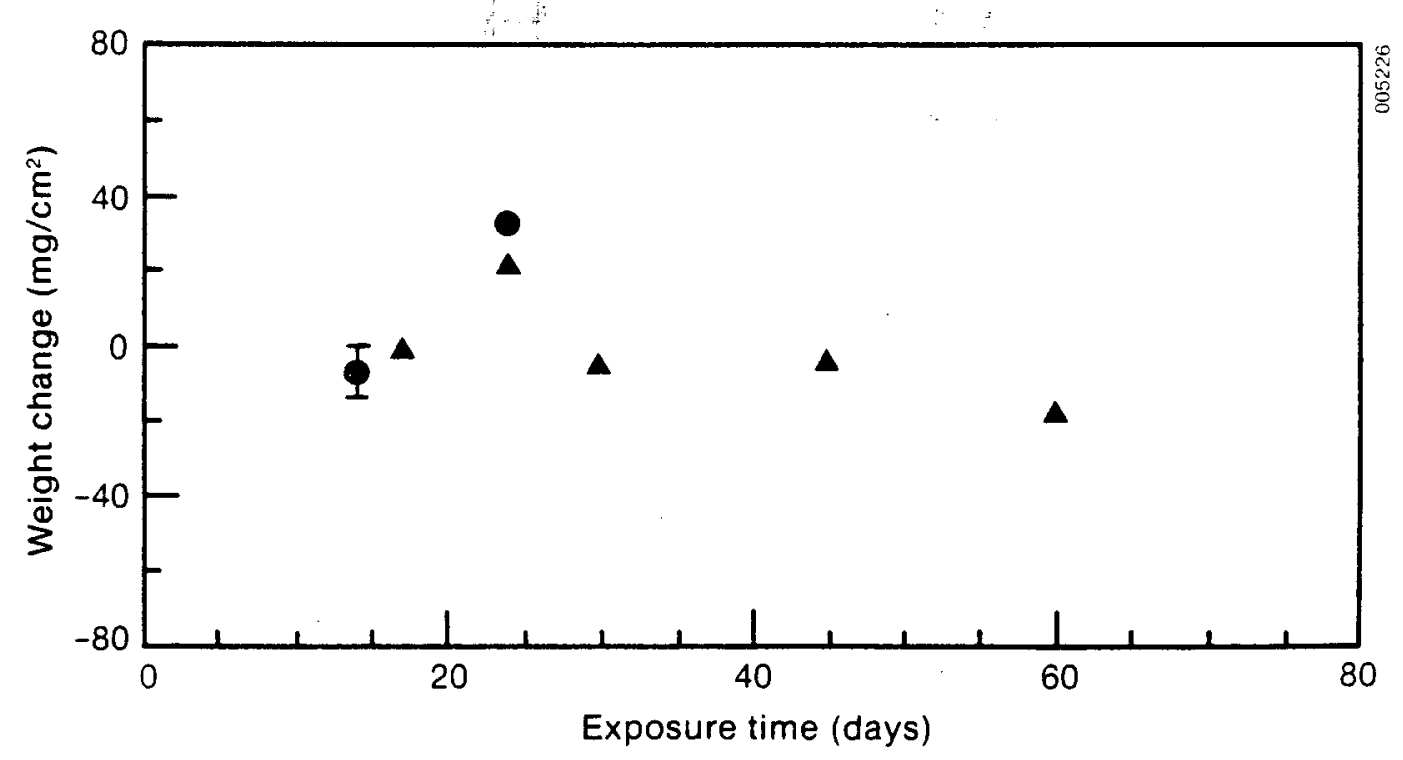

Figure 3-5. Weight Change of Nickel after Exposure to Eutectic LiNaR Salt at $900^{\circ} \mathrm{C}$. Salt conditions: - low $\mathrm{O}_{2}$, high $\mathrm{CO}_{2}$; $\checkmark$ high $\mathrm{O}_{2}$, high $\mathrm{CO}_{2}$.
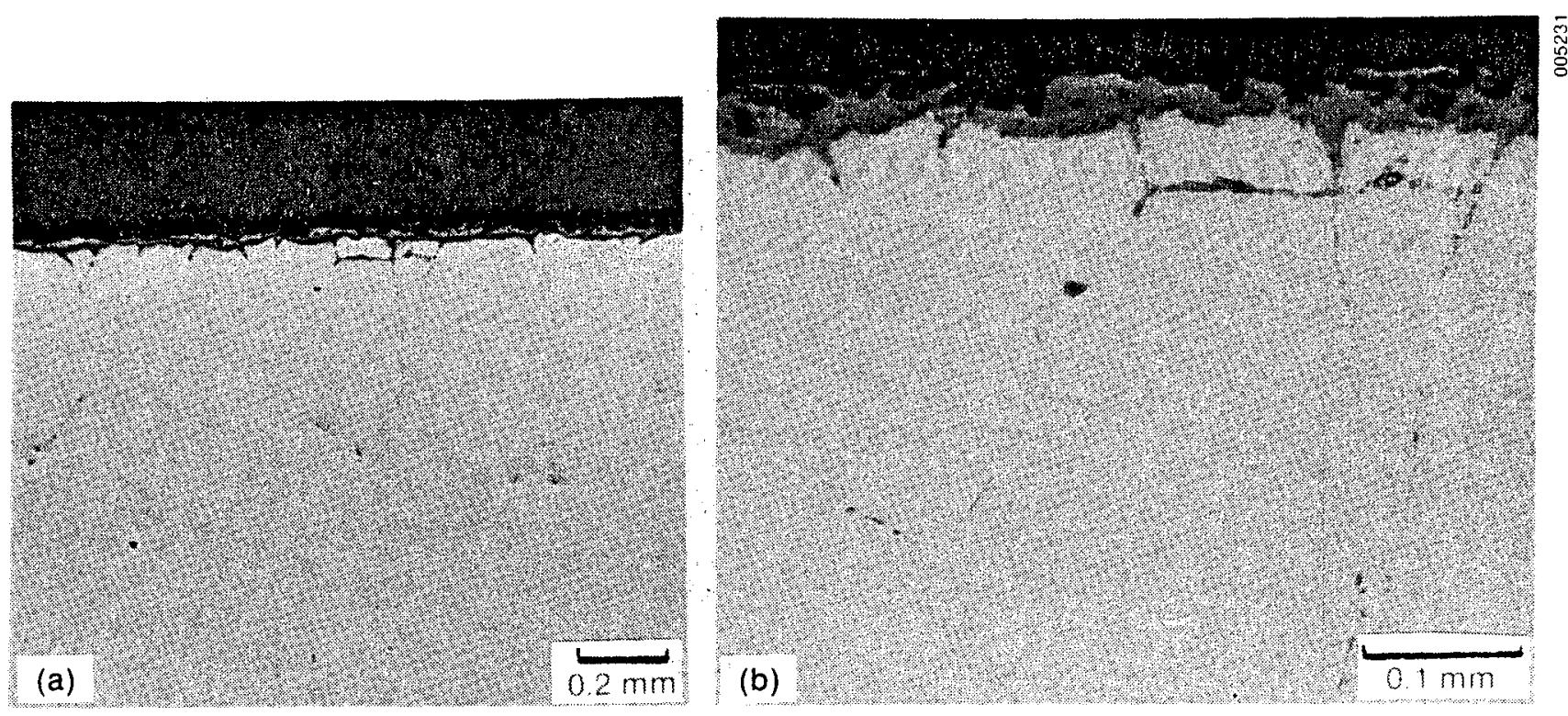

Figure 3-6. Commercial Nickel Alloy, Cabot Alloy 201, after Exposure to Eutectic LiNaR Salt at $900^{\circ} \mathrm{C}$ for 60 Days, Bubbled with 717 Argon197 Oxygen 
regarded as speculative. The corrosion rate for the low oxygen potential condition using the same assumptions would be two or three times higher.

\subsection{Corrosion of Nickel}

The results from weight change studies of nickel in eutectic LiNak at $900^{\circ} \mathrm{C}$ are shown in Figure 3-5. Two types of experiments were conducted, both using the high acidity condition. The low oxygen potential experiment lasted 14 days and used a $99.99 \%$ pure nickel; the high oxygen potential experiment was conducted using a nickel of commercial purity, Cabot 201. Table 3-3 shows that coupons experienced weight losses of less than $20 \mathrm{mg} / \mathrm{cm}^{2}$ for both conditions, which is less than those observed for the Inconel 600 and the Hastelloy N. Metallographic results are given in Table 3-3 and in Figure 3-6.
As with the Inconel 600 and Hastelloy $N$, it is speculative to derive corrosion rates for the nickel from the data in Table 3-3. However, using the same assumption of linear metal loss rate as used for the Inconel 600 and Hastelloy $N$ and using the data at 60 days, we would predict a corrosion rate of $3 \mathrm{~mm} / \mathrm{yr}$ per side for the Cabot 201. Table 3-3 shows, however, that this 1 inear assumption may lead to higher corrosion rates than warranted since the the depth of corrosion appears to remain constant between 17 and 60 days. Further study should be done on this alloy to determine whether additional metal reacts in the molten salt after the initial corrosion has occurred, as suggested by the data in Table 3-3.

\subsection{Corrosion of Haynes 556}

The results of the weight loss studies for Haynes 556 shown in Figure 3-7 indicate large weight gains occurred after 3 and 6 days.

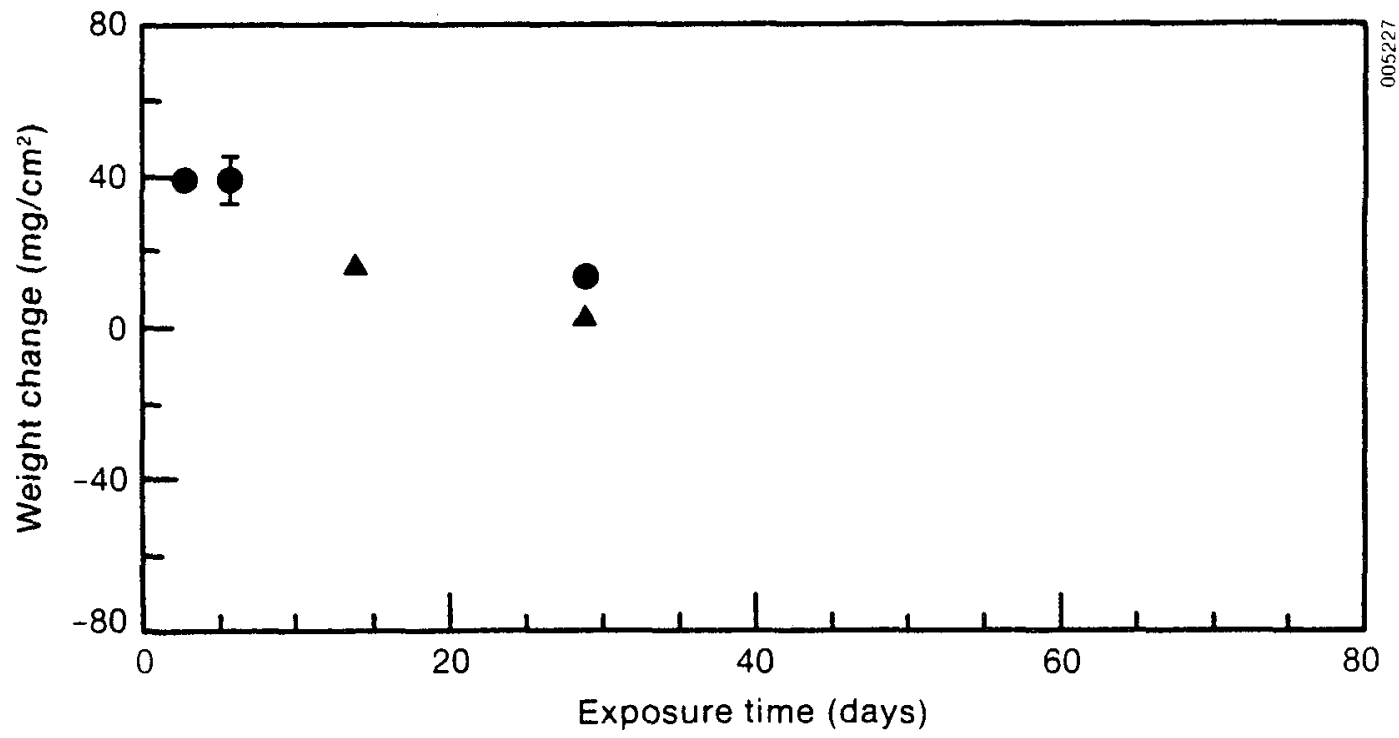

Figure 3-7. Weight Change of Haynes 556 ( 1 low $\mathrm{O}_{2}$, low $\mathrm{CO}_{2}$ ) and Cabot $800 \mathrm{H}$ ( $\triangle$ low $\mathrm{O}_{2}$, high $\mathrm{CO}_{2}$ ) after Exposure to Eutectic LiNaR Salt at $900^{\circ} \mathrm{C}$ 


\section{SEPI 綽}

PR-2561
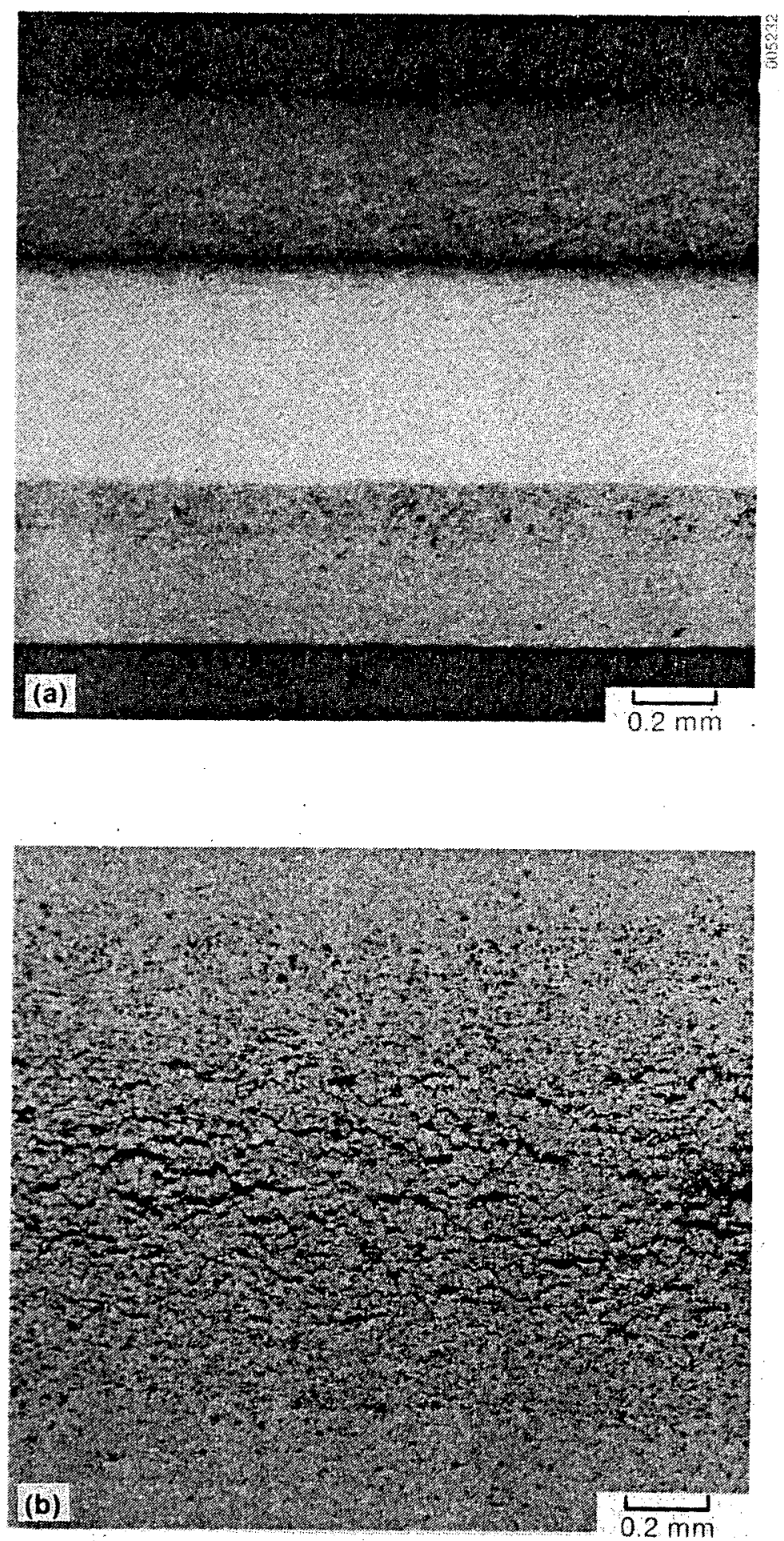

Figure 3-8. Metallographic Sections of Haynes 556 after Exposure to Eutectic LiNaR Salt for 3 Days (A) and 6 Days (B) at $900^{\circ} \mathrm{C}$ 


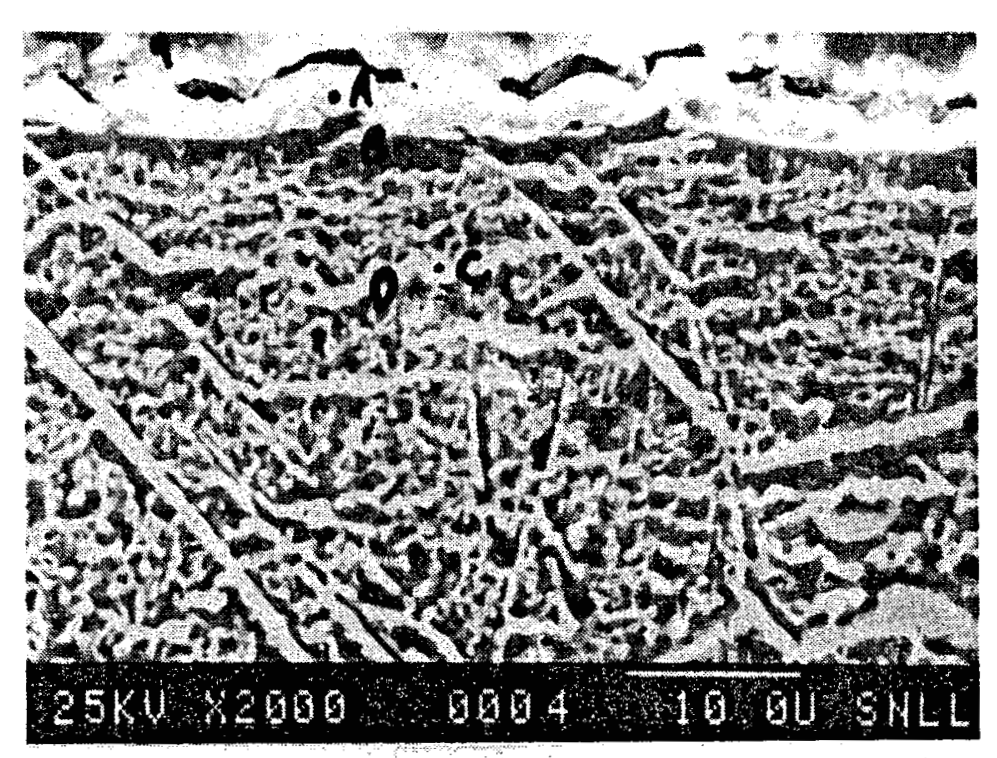

(a)

เ

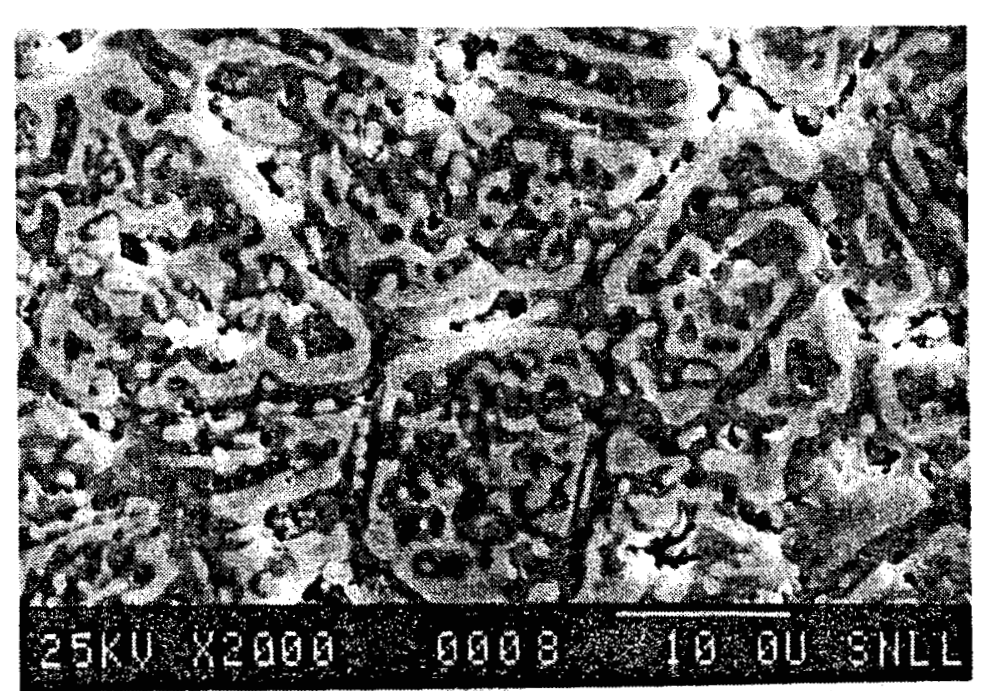

(c)

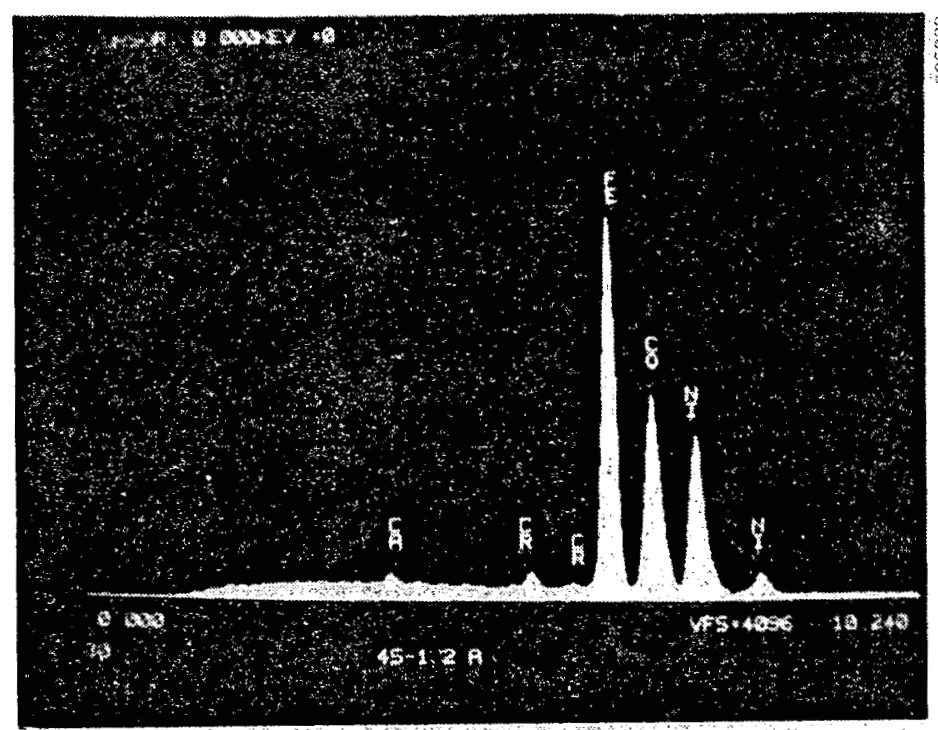

(b) EDS areas A and C

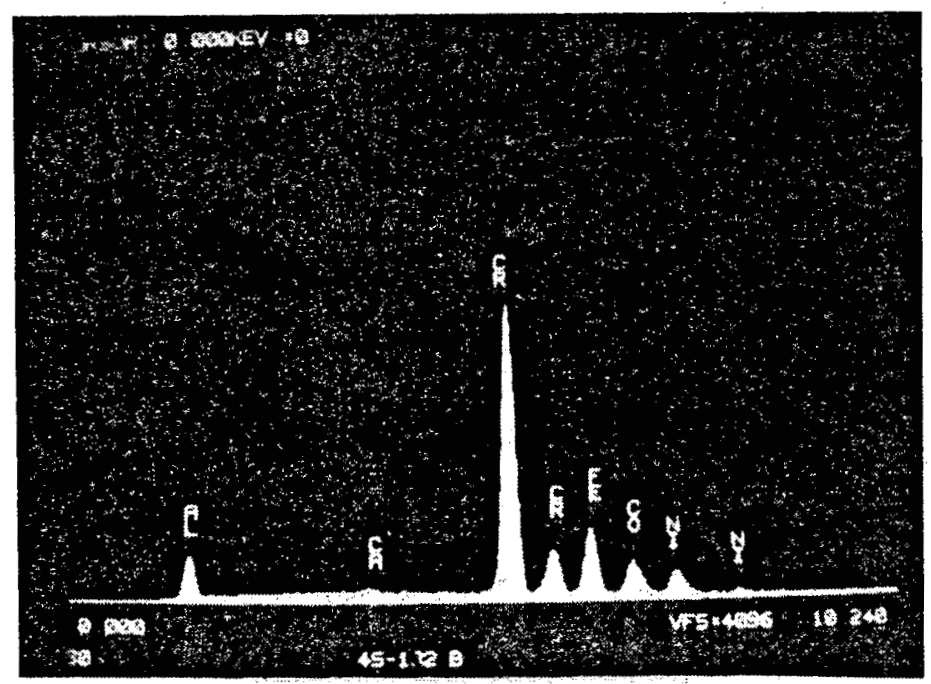

(d) EDS areas $B$ and D 
Micrographs from metallographic examination of coupons after 3 and 6 days of exposure to the molten salt are shown in Eigure 3-8. The metal loss per side determined from these micrographs would lead to corrosion rates of 34 and $>33 \mathrm{~mm} / \mathrm{yr}$ per side if we assume the same linear corrosion as assumed for the previously discussed alloys.

Bradshaw (1984) conducted a scanning electron microscopy (SEM) evaluation of the Haynes 556 alloy using energy dispersive spectroscopy (EDS) for elemental analysis of the corrosion product. The results are shown in Figure 3-9. The light areas labeled $A$ and $C$ were identified as metal and contained the major components of the alloy, $\mathrm{Fe}, \mathrm{Co}$, and $\mathrm{Ni}$, at about the expected intensity except for chromium, which should have about the same intensity as the others.

However, in the grey areas, labeled B and $D$, which were identified as oxide, the major element by far was chromium with substantially less $\mathrm{Fe}$, Co, and $\mathrm{Ni}$.

The SEM micrograph shows the corrosion product to be an interpenetrating mixture of metal and oxide similar to that reported by Coyle, Thomas, and Lai (1984) for a number of superalloys that were exposed to eutectic sodium-potassium carbonate at $900^{\circ} \mathrm{C}$ for 21 days. The chromium appears to be preferentially removed from the alloy when it is attacked by the $900^{\circ} \mathrm{C}$ molten salt, and the other alloy ingredients are left behind in the metal.

\subsection{Corrosion of Cabot 214 and Cabot $800 \mathrm{H}$}

Cabot 214 and Cabot $800 \mathrm{H}$ were tested in eutectic $(\mathrm{Li}, \mathrm{Na}, \mathrm{K}){ }_{2} \mathrm{CO}_{3}$ at $900^{\circ} \mathrm{C}$ using the low oxygen potential and high acidity condition. After 9 days, the Cabot 214 coupons had swollen to the extent that they could not be removed from the alumina sample holder. After 14 days, the Cabot $800 \mathrm{H}$ coupons had swollen so much that they could not be removed from the sample holder. Figure 3-7 shows the weight gain for the Cabot $800 \mathrm{H}$; the data were corrected for the weight of the sample holder rod that was inseparable from the coupon.

The Cabot 214 is an alloy that contains aluminum and is designed to form a protective aluminum oxide film. In view of the improved corrosion resistance of other alloys tested under conditions of high oxygen potential and the good corrosion resistance of alumina that was reported by Coyle, Thomas, and Schissel (1985) and Grantham and Ferry (1976), a reevaluation of this alloy under the high oxygen potential condition could prove the alloy to be much more corrosion resistant than the present results indicate. 


\subsection{SUMMARY AND CONCLUSIONS}

A number of alloys, Inconel 600 , Hastelloy N, Cabot 201 (nickel), Haynes 556, Cabot 214, and Cabot $800 \mathrm{H}$, that showed the best corrosion resistance to molten carbonate salt at $900^{\circ} \mathrm{C}$ in earlier exploratory corrosion tests were tested for corrosion resistance in eutectic lithium-sodium-potassium carbonate at $900^{\circ} \mathrm{C}$. Weight change as a function of time and metallographic studies were done to evaluate the stability to corrosion.

- We found that for Inconel 600 and Hastelloy $\mathbf{N}$ tested in molten salt with a $22 \%$ oxygen purge, the corrosion was dramatically less than for these alloys tested with purge gas containing about one- tenth of the oxygen.

- Metallographic examination of Inconel 600, Hastelloy $\mathrm{N}$, and Cabot 201 in salt with high oxygen content suggested that a thick but protective corrosion product formed.

- The corrosion rates for Inconel 600 under the high oxygen condition could reasonably be expected to be below $1 \mathrm{~mm} / \mathrm{yr}$ per side; to demonstrate this would require more detailed study over a longer period of time.

- Aluminum-containing alloys, such as Cabot 214, and other alloys that were tested only with low oxygen content purge gas should be reevaluated in the high oxygen potential conditions. 


\subsection{REFERENCES}

Coyle, R. T., R. J. Copeland, R. W. Burrows, and R. M. Goggin, 1983, "High Temperature Molten Salts for Use in Solar Thermal Energy Systems," Proceedings of the Sixth International Symposium on Salt, Toronto, Canada, 24-28 May 1983, and SERI/TP-255-2001, Golden, CO: Solar Energy Research Institute.

Coyle, R. T., R. W. Burrows, R. M. Goggin, and T. M. Thomas, 1984, Exploratory Corrosion Tests on Materials and Fluids for Advanced $\mathrm{High}-$ Temperature Molten Salt Storage, SERI/TR-255-2199, Golden, CO: Solar Energy Research Institute.

Coyle, R. T., T. M. Thomas, and P. Schissel, 1985, The Corrosion of Materials in Molten Alkali Carbonate Salt at $900^{\circ} \mathrm{C}$, SERI/TR-2552553, Golden, CO: Solar Energy Research Institute.

Coyle, R. T., T. M. Thomas, and G. Y. Lai, 1984, "Exploratory Corrosion Tests on Alloys in Molten Salts at $900^{\circ} \mathrm{C}, "$ Proceedings of High Temperature Corrosion in Energy Systems: An International Symposium, Detroit, MI, 17-19 Sept. 1984 and SERI/TP-255-2492, Golden, CO: Solar Energy Research Institute.

Bradshaw, R. W., 1983, "Corrosion of $316 \mathrm{SS}$ and IN800 in Molten $\mathrm{NaNO}_{3}-$ $\mathrm{KNO}_{3}$," Proceedings of the Symposium on Corrosion in Batteries and Fuel Cells and Corrosion in Solar Energy Systems, C. J. Johnson and S. L. Pohlman, eds., Pennington, NJ: The Electrochemical Society, Inc., Vol 83 , No. 1 .

Bradshaw, R. W., 1984, Private Communications, Livermore, CA: Sandia National Laboratories.

Grantham, L. F., and P. B. Ferry, 1976, "Corrosion in Alkali Metal Carbonate-Based Melts," Proceedings of the International symposium on Molten Salts, J. P. Pemsler et al., eds., Princeton, NJ: The Electrochemical Society, Inc. 


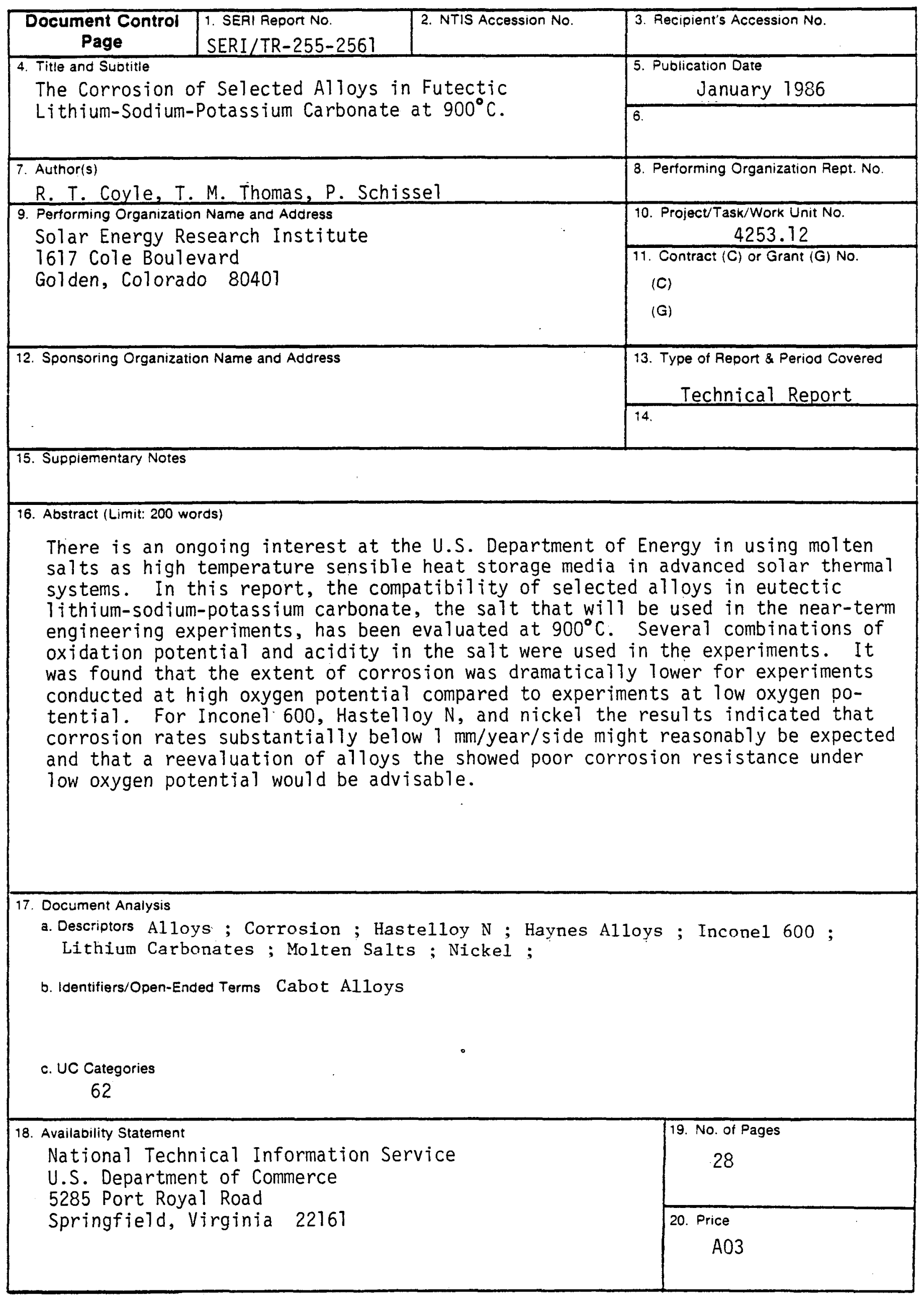

